\title{
The Importance of Hydraulic Structures for Society: Quay Walls and Dikes in the Netherlands
}

\author{
de Gijt, J.G. ${ }^{1}$
}

\begin{abstract}
Since mankind exists, men have undertaken engineering activities to make their life more pleasant and secure. However this has not been an easy task, especially in the past. The knowledge of mathematics and physics to describe engineering problems became available only since 1400-1500. Nevertheless, great achievements have been made by man before that time, e.g. the pyramids in Egypt, the first sluice in China, the Borobudur temple in Indonesia, and the design and building activities of the Inca's in South America. To illustrate this development, also the world economy, world ecology will be shortly mentioned. The structures that are briefly discussed in this paper are: soil and concrete dams for generating electricity, reservoirs for irrigation and drinking water, dikes, sluices, inland and sea, tunnels, and quay walls. This paper presents an overview of hydraulic structures in general with the emphasis on quay walls and dikes in the Netherlands. Examples of these structures will be discussed illustrating present state of the art and also with a view to the future. Conclusions and recommendations are given to enhance the knowledge of hydraulic structures.
\end{abstract}

Keywords: Quaywalls; shiplocks; dikes; settlement; ship; probabilistic design.

\section{Introduction}

During the long time that mankind exists, there has been, and there still is a struggle to improve the quality of life. This is a very complicated process. However, we as humans and engineers should strive to make living better and also more sustainable through taking environment into account. We, as engineers, can play an important role to achieve this.

The origin of engineering started with the branch of militarily engineering for defending lives and property. However, since about 1800-1850, the civil engineering discipline exists, starting in France and spreading over the world, boosted by the industrial revolution. Since that time, civil engineers began to design dams, bridges, roads, dikes, storm surge barriers, quay walls etc. practicing a scientific approach which could make use of the developments in physics, mathematics, and since 1400-1500, improved knowledge of materials. They have applied the work of the Arabic and Indian people for mathematics, Da Vinci and many others.

In this respect, hydraulic structures like dams, locks, quay walls, dikes, and storm surge barriers have been designed all over the world in response to the need and development of societies. This paper will discuss the development of different type of hydraulic structures which some special attention to dikes and quay walls which have been designed and constructed in the Netherlands.

\footnotetext{
${ }^{1}$ Delft University of Technology, Faculty of Civil Engineering Section of Hydraulic Structures and Flood Risk Analysis, Delft, NETHERLAND. Email: j.g.degijt@tudelft.nl
}

\section{Type of Hydraulic Structures}

Throughout history, several types of hydraulic structures have been invented, designed and constructed.

In Table 1 the main types of hydraulic structures are listed together with the use of these structures.

Table 1. Overview of Origin of Different Structures

\begin{tabular}{|c|c|c|c|}
\hline $\begin{array}{l}\text { Type of } \\
\text { structure }\end{array}$ & $\begin{array}{l}\text { First in the } \\
\text { world }\end{array}$ & First in Europe & Biggest \\
\hline Quay wall & $\begin{array}{l}\text { India } 2400 \mathrm{BC} \\
\text { Lothal }\end{array}$ & $\begin{array}{l}\text { Italy } 400 \\
\text { Cesaere }\end{array}$ & $\begin{array}{l}\text { The Nether- } \\
\text { lands } 1990 \\
\text { Rotterdam }\end{array}$ \\
\hline Lock & $\begin{array}{l}\text { China } 984 \\
\text { Grand Canal }\end{array}$ & $\begin{array}{l}\text { The Nether- } \\
\text { lands } 1300 \\
\text { Vreeswijk }\end{array}$ & $\begin{array}{l}\text { Belgium } 2015 \\
\text { Deurganck- } \\
\text { dok }\end{array}$ \\
\hline Dam & $\begin{array}{l}\text { Jordan } 3000 \\
\text { BC } \\
\text { Jawa dam }\end{array}$ & $\begin{array}{l}\text { Spain Roman } \\
\text { Dam at } \\
\text { Cornalvo } 0\end{array}$ & $\begin{array}{l}\text { China } 2002 \\
\text { Three Gorges } \\
\text { dam }\end{array}$ \\
\hline $\begin{array}{l}\text { Storm surge } \\
\text { barrier }\end{array}$ & $\begin{array}{l}\text { The Nether- } \\
\text { lands } 0 \\
\text { Friesland } \\
\text { The Nether- } \\
\text { lands } \\
1975\end{array}$ & $\begin{array}{l}\text { The Nether- } \\
\text { lands } 0 \\
\text { Friesland } \\
\text { The Nether- } \\
\text { lands } 1975 \\
\text { Eastern Scheldt } \\
\text { Barrier }\end{array}$ & $\begin{array}{l}\text { The Nether- } \\
\text { lands } 1942 \\
\text { Afsluitdijk } \\
\text { The Nether- } \\
\text { lands } 1975\end{array}$ \\
\hline
\end{tabular}

\section{Dams}

The first dam, the Jawa dam, made for drinking water purposes was built in Jordan in 3000 BC. Later, the dams evolved from earth constructed dams to quarry material and finally to reinforced concrete dams. Also, the function of the dams has 
changed from only water supply to agriculture, shipping and energy. Experience has shown that dam construction has not always had only positive effects [1]. The construction materials that are and have been used for building dams are soil, wood stones, and concrete. Dams are built for several functions such as water supply, power generation, and navigation. Today, dams are built in estuaries to generate energy following the first dam in the Rance estuary in France.

The disadvantage with dams is the accumulation of slib and the influence on the environment of animals. In recent times, advantages has been made by introducing fish traps and introduction of environmental impacts study that incorporate all developmental aspects. The biggest dam at this moment is the dam in the Three Georges dam in China (Figure 1).

The types of dams can be grouped as follows:

- Gravity dams

- Arch gravity dams

- Barrages

- Embankment dams

- Rock fill dams

- Concrete faced rock fill dams

\section{Locks}

The oldest shipping lock was constructed in China for the Grand Canal in 984. Before that time, the canal was divided in sections by dams to control the water levels and slipways consisted mostly of a row of trees over which the ships were pulled over the dam to the other part of the canal. This caused a considerable of damage the ships.

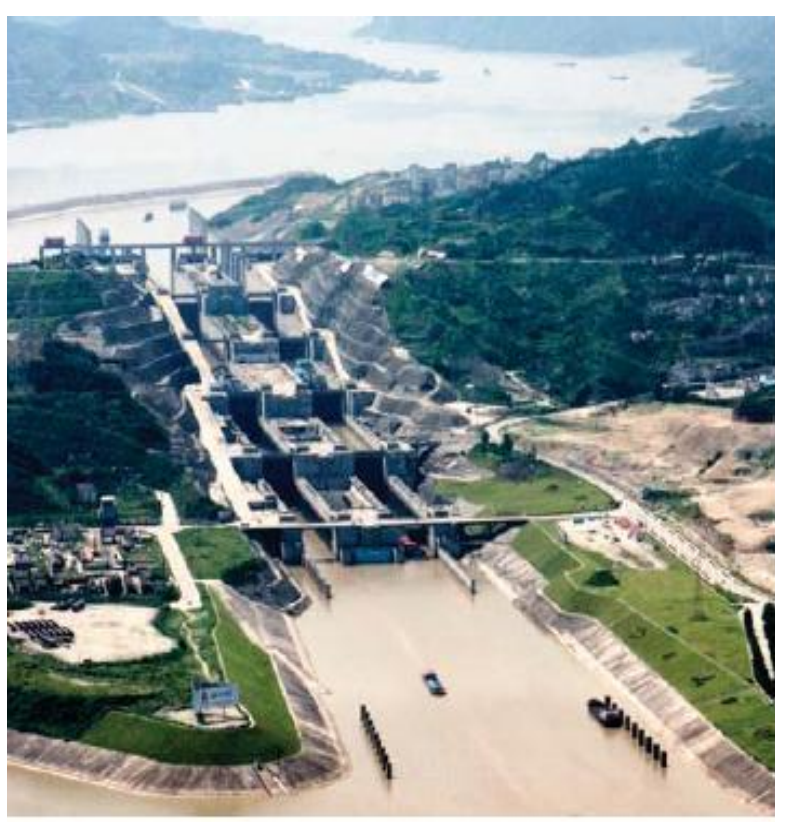

Aerial View of the Three Gorges Locks

Figure 1. Three Gorges Lock, China [2-4]
In Europe, the first lock was introduced in the Netherlands, Vreeswijk in 1358. This construction was a so-called pounded lock with guillotine doors. Recently an old lock in the Rotte River near Rotterdam has been rebuilt. This has been made possible by scanning at location, which revealed enough information for rebuilding.

At this moment the biggest lock of the world is in Kallo, Belgium (Figure 2).

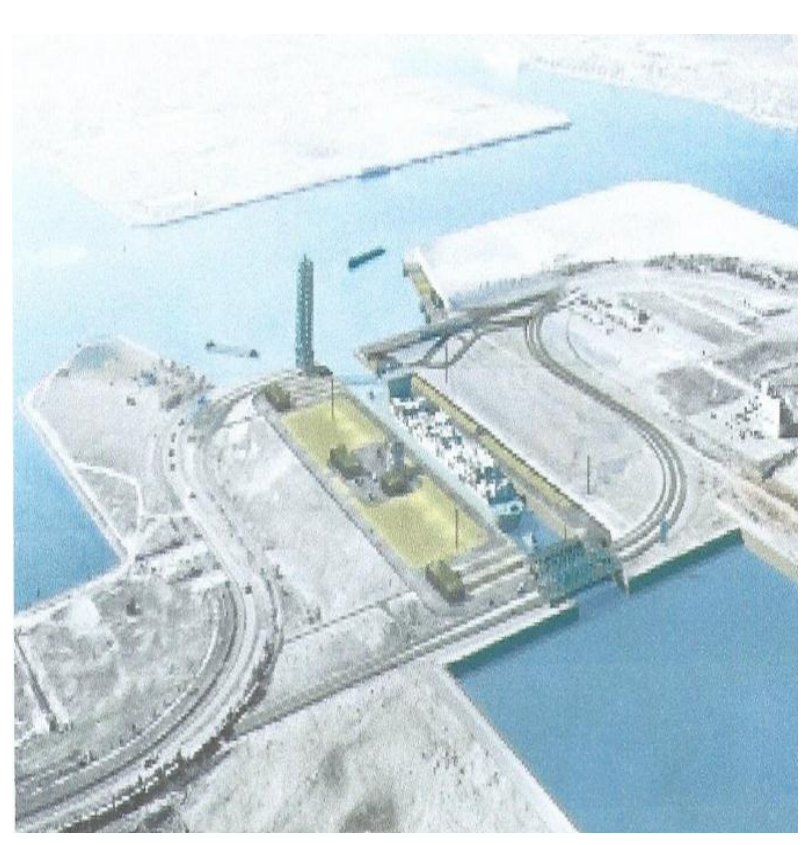

Figure 2. Areal Vieuw Deurganckdoksluis, Kallo, Belgium $[5,6]$

\section{Dikes}

Without dikes nearly $70 \%$ of the Netherlands would have been flooded. In earlier times people built hills, terps as indicated in Figure 3, to be protected for high water. Later these hills were connected by dikes which created the first polders.

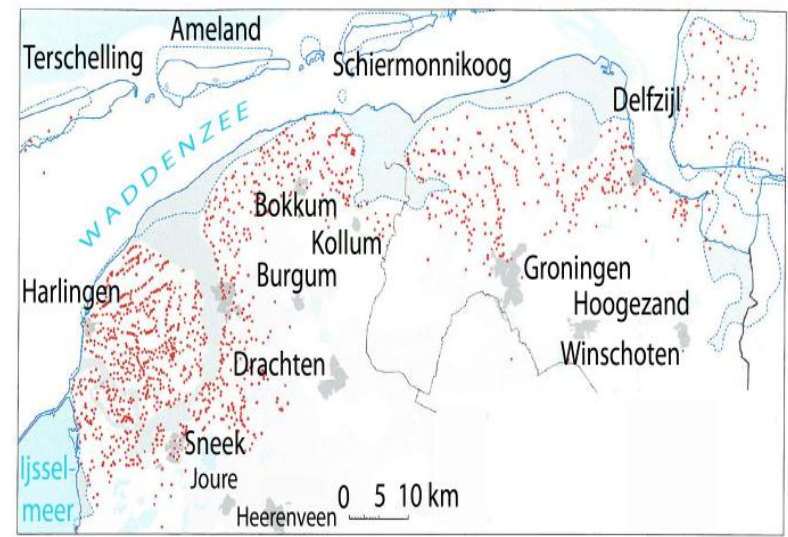

Figure 3. Map Showing the Terps 2000 Years Ago in Friesland [7] 
During the 1400 and 1700, many areas in West and North Netherlands were excavated for peat which was used as fuel. However, due to this digging of peat, illnesses like malaria were introduced but also the ground level settles due to dewatering as indicated in Figure 4. At this stage, the West of the Netherlands settled about 2 meters in approximately 300 years which is also indicated in Figure 5. The lowest area in the Netherlands is close to Rotterdam, The Alexander polder where the ground level is ca 6 $\mathrm{m}$ below average sea level. In Figure 5 the settlement of different Delta Cities in the world is shown.

To reduce the effects of continuing settlement, drinking water extraction underneath the soft layers is forbidden.

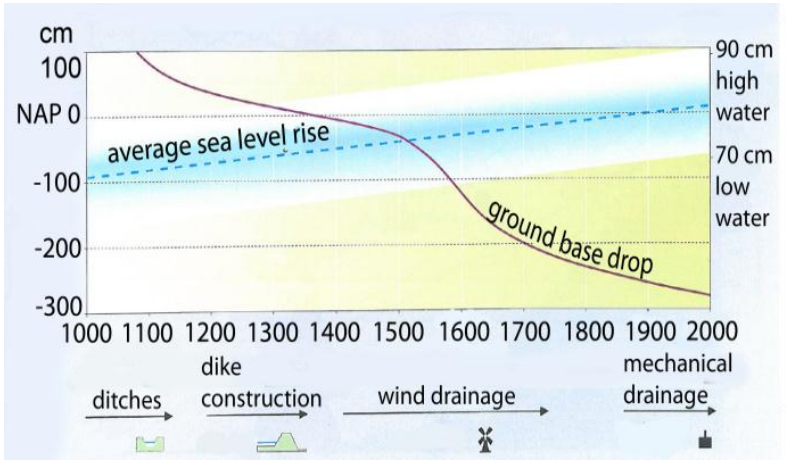

Figure 4. Showing Dewatering Principles with Time and the Settlement of Ground Level [8]

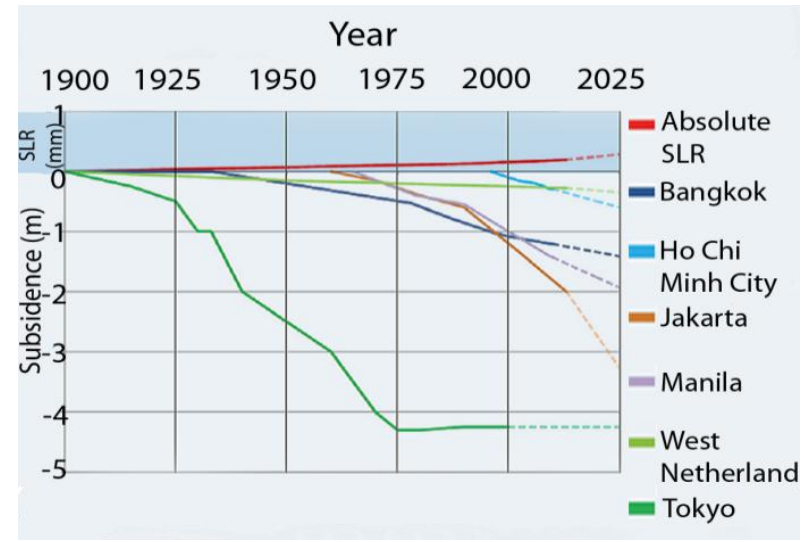

Figure 5. Sea Level Rise and Settlement of Some Delta Cities [9]

At the same time, the dunes or the natural dikes are used to catch rainwater. In addition, the artificial water from the river Maas and Rhine is used to create fresh water bell which is now for more than 100 years as drinking water supply in areas of Amsterdam and The Hague. An example of this fresh water bell is presented in Figure 6.

This Figure 6 shows the soil conditions in the Western part of the Netherlands. Along the West part the coastline dunes are present. In the middle the polder land is situated. This area has to be dewatered and protected against salt intrusion

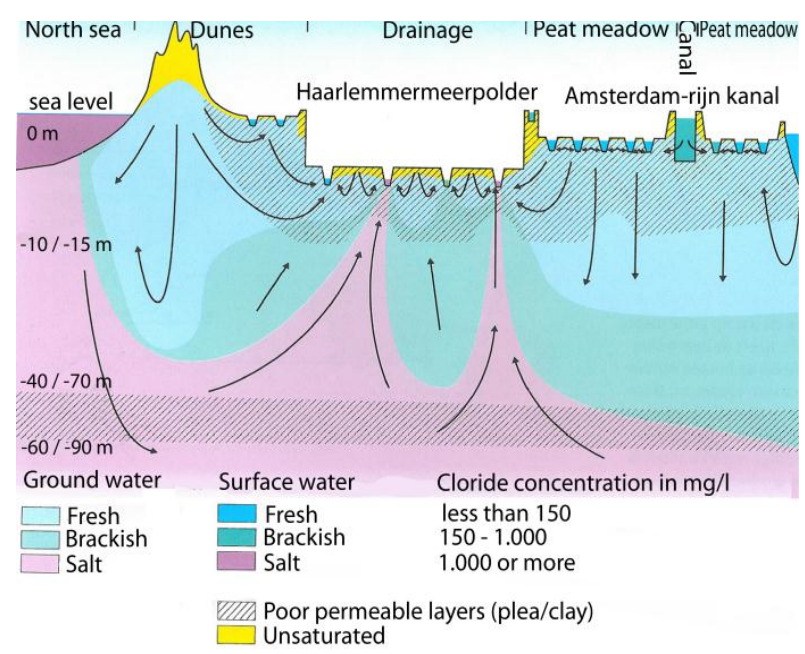

Figure 6. Cross Section Over the Western Part of the Netherlands [8]

If we consider the situation along the rivers, we can make the following observations. In the past, hardly any dikes were present, so a lot of flooding occurred. Then we had a phase of constructing dikes for preventing flooding. However this also meant that the space for the river was limited and we had higher water levels than in the past. This situation could worsen due to climate change.

Therefore, at the moment a great programme, Space for the river, is underway to create more space for the water in the river and thus less flooding as shown in Figure 7.

This is accompanied with a probabilistic approach for design of dikes which incorporates the effect of high water levels, risk for people, industry, and environment.

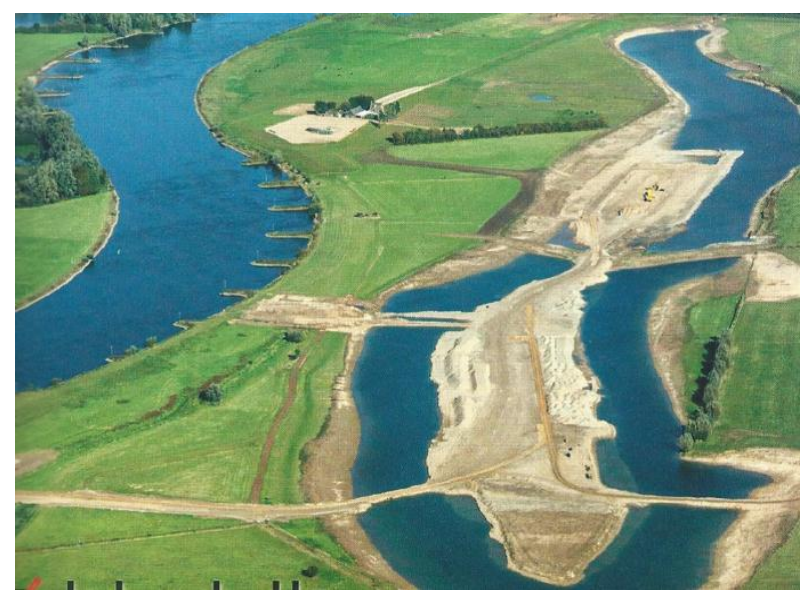

Figure 7. Extra Room for the River Ijssel to Reduce High Water Levels, Munnikenhank, The Netherlands [10] 


\section{Storm Surge Barriers}

The South West of the Netherlands has been flooded several times. This has finally resulted in building the dams and barrier in the Oosterschelde, The Netherlands (Figure 8). Originally this was designed as a closed dam. However due to environmental aspects, the solution was altered to a construction with openings including mitre gates. In this way the tidal variations could be accommodated.

At this moment 153 storm surge barriers [11] have been built around the world. In Mooyaaart et al. [11] the construction costs have been estimated. The costs can be determined by the length of the structure, the hydraulic head, therefore great difference in costs are present. Roughly one could state that one running of barrier costs about $€ 2.2$ million with a standard deviation of $56 \%$.

At the moment the Afsluitdijk, Figure 9, is being restored and also a tidal river is introduced with a length of a few kilometres to prevent siltation of the Ijselmeer. The river can be closed with storms and high tides at the Waddenzee. This solution, Figure 10, enables fish to travel from the Waddenzee and the Ijsselmeer.

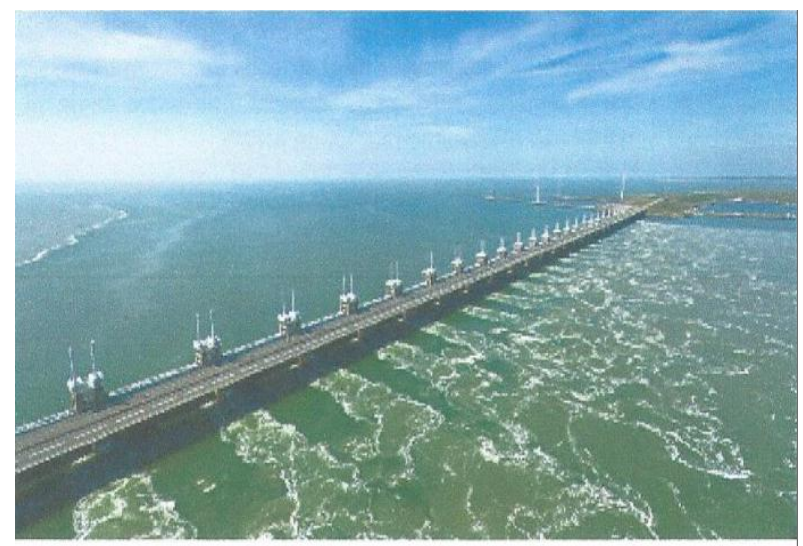

Figure 8. Storm Surge Barrier Oosterschelde, The Netherlands [11]

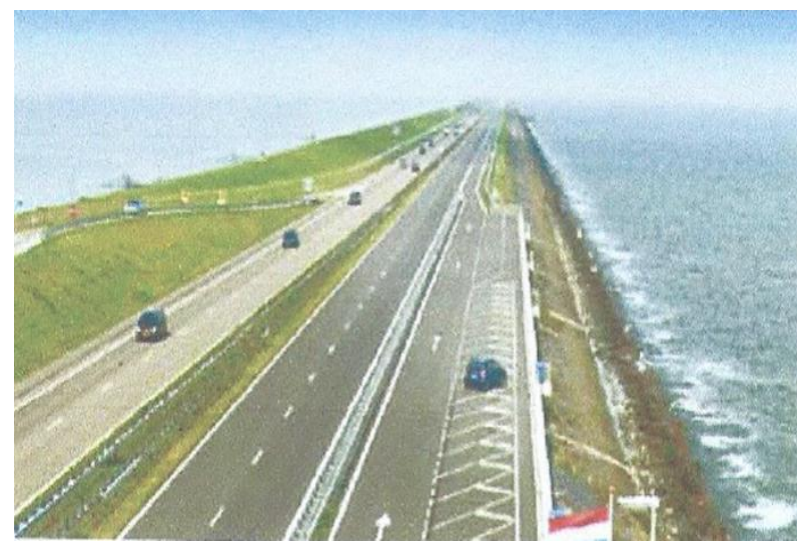

Figure 9. Afsluitdijk, The Netherlands [12]

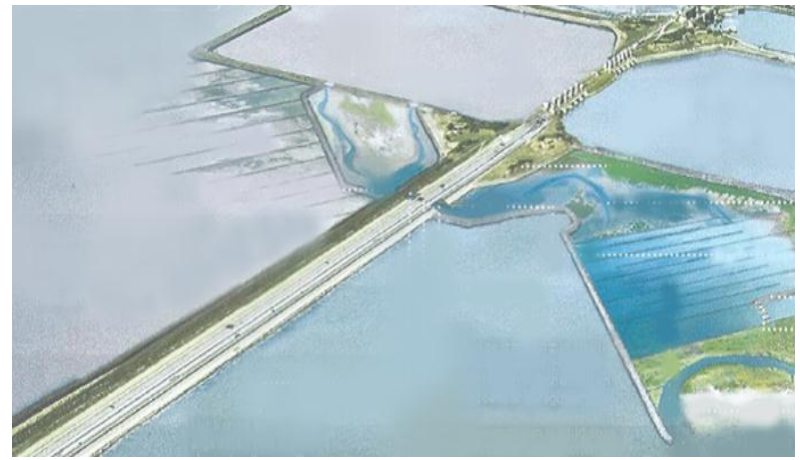

Figure 10. River through Afsluitdijk, the Netherlands [12]

\section{World Economy}

The world economy is not a constant but very changeable. As in indicated in Figure 11, China and India had $80 \%$ of the GDP (Gross Domestic Product) in the year 1 . That have changed due discovery journey by countries from Western Europe. After the second world was, America had the most share of the world GDP. However, today, China and India have again $60 \%$ of the world GDP.

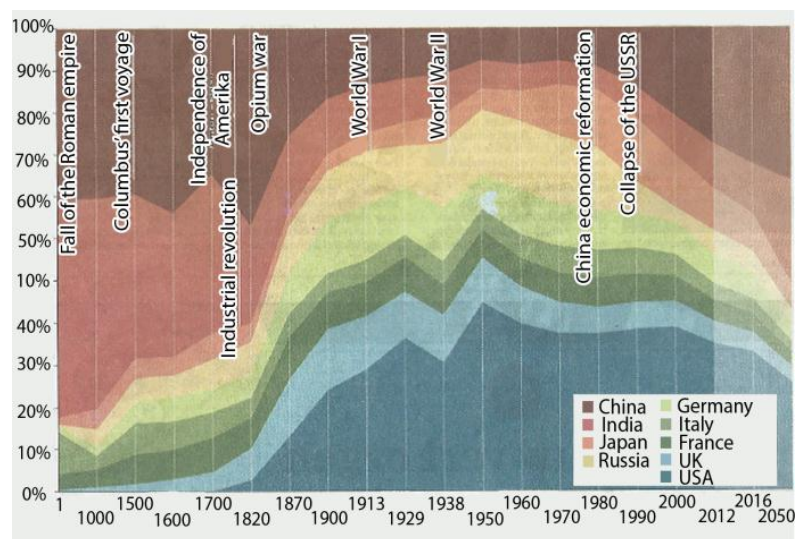

Figure 11. GDP for Several Countries from Year 1 to 2500

\section{Quay Walls}

The oldest quay walls were built in India. In Figure12 a photo of this quay wall is presented.

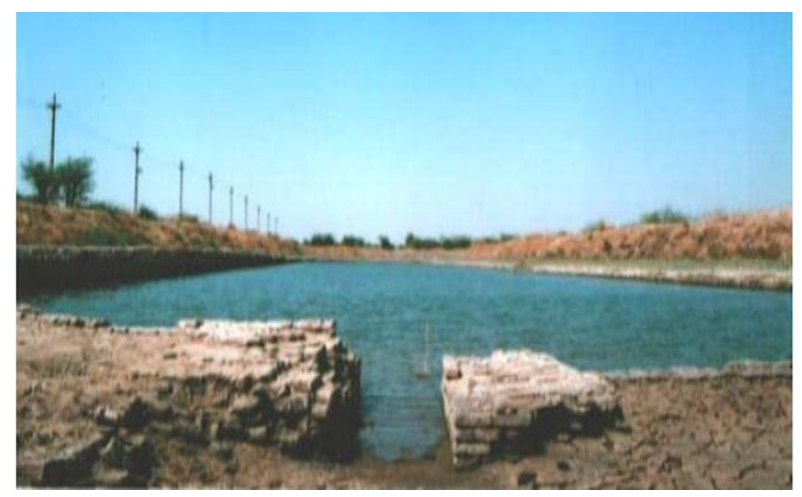

Figure 12. Brick Quay Wall Lothal, India [7] 
This quay wall was built by placing bricks together. The bricks were dried in the sun. Since that time several types of quay walls have been developed like:

- gravity wall

- sheet pile wall

- relieving floor wall

- jetty type or wharf

This development has been possible due to the fact that we have learnt how to use materials and improvement in construction techniques.

\section{Ship Development}

This Figure 13 indicates the ship develoment in general. For container ships, one can notice that in the last 5 years there is a big increase in TEU capacity up to 20000 TEU.

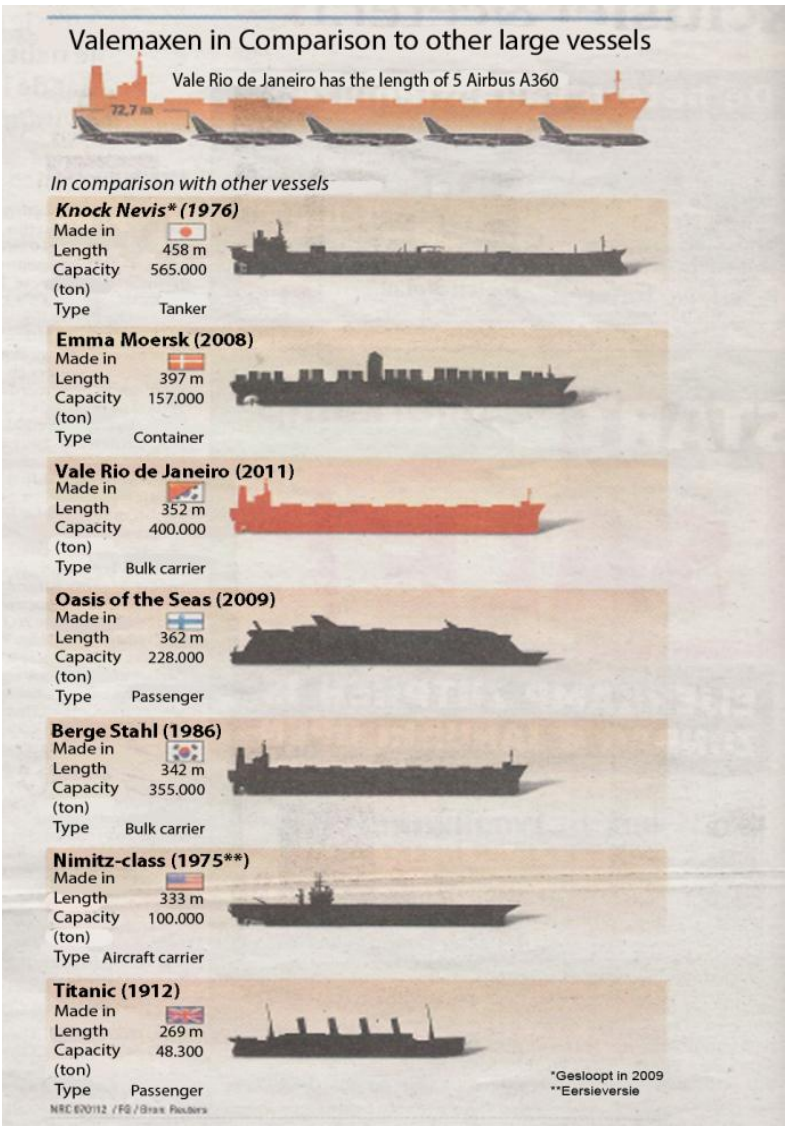

Figure 13. Ship Size Development

It is anticipated, based on these data, that ships will have maximum dimensions of $500 \mathrm{~m}$ length, $24 \mathrm{~m}$ draught and $70 \mathrm{~m}$ width. This will result in 2500030000 TEU capacity for container vessels .

In Rotterdam, a former fishing town, the port activities started after 1664. In Figure 14 the present situation in Rotterdam is shown including the development of the port in time.

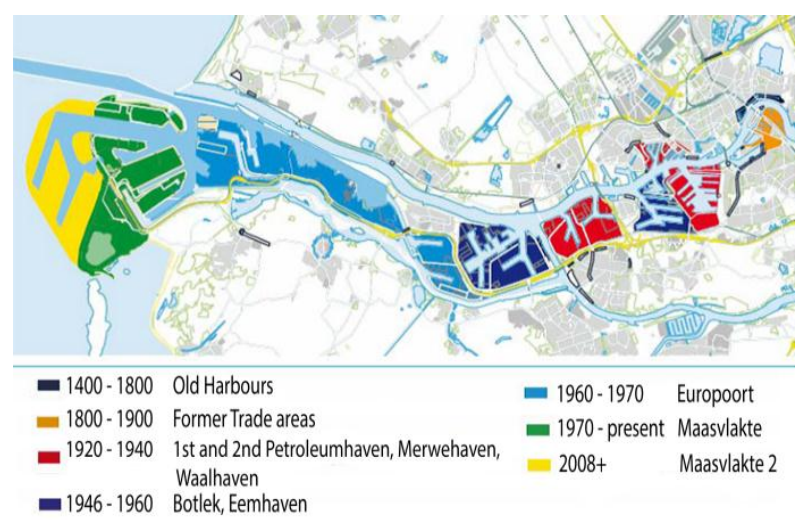

Figure 14. Present Situation Port of Rotterdam [13]

Wth the use of a diving bell, Figure 15, one could work under the waterlevel independent of the tide and thus increasing the production time. A disadvantage of this working method is the chance of the caisson disease if one is too long working under high pressure and/or goes too quickly to the surface.

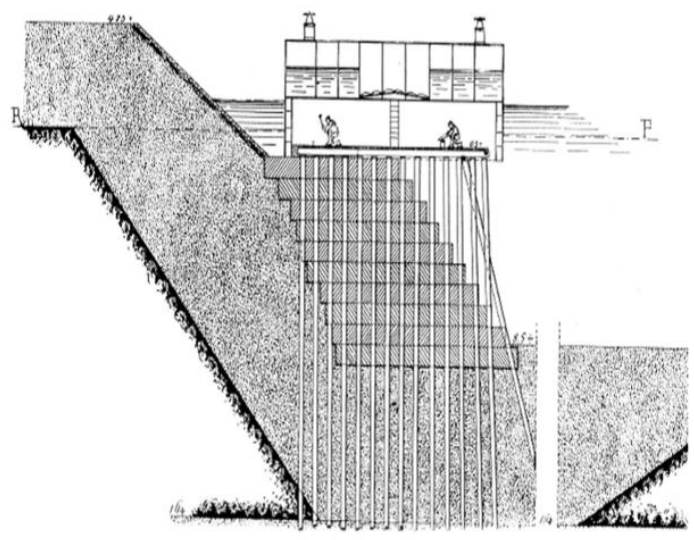

Figure 15. Construction of a Quay Wall using a Diving Bell 1930 in Rotterdam

In Figure 16, examples of structures were built when no steel or concrete was available. Thus local materials were used, wood and fascine mattresses. Initially only vertical piles were installed, later, followed by additional inclined piles to increase the horizontal stability of the quay wall.

\section{QUAY WALL ALONG THE BOOMPJES}
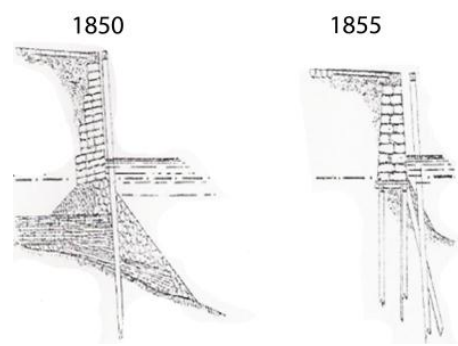

QUAY WALL ALONG THE OOSTER QUAY

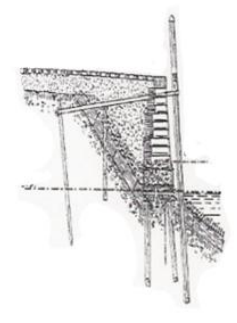

Figure 16. A Selection of Quay Walls being Built in Rotterdam before 1900 
Most of the quay walls today in Rotterdam consists of the relieving platform form type, two examples are presented in Figure 17.

For the Maasvlakte 2 extension, which will be operational in 2015, diaphragm walls have been built.

The retaining height of these structures is approximately 29 to $31 \mathrm{~m}$. The costs of quay walls [14] are for $90-95 \%$ determined by the retaining height. This implies that costs are $€ 1500 \mathrm{~m}^{2} / \mathrm{m}$ height $+/$ - $20 \%$.
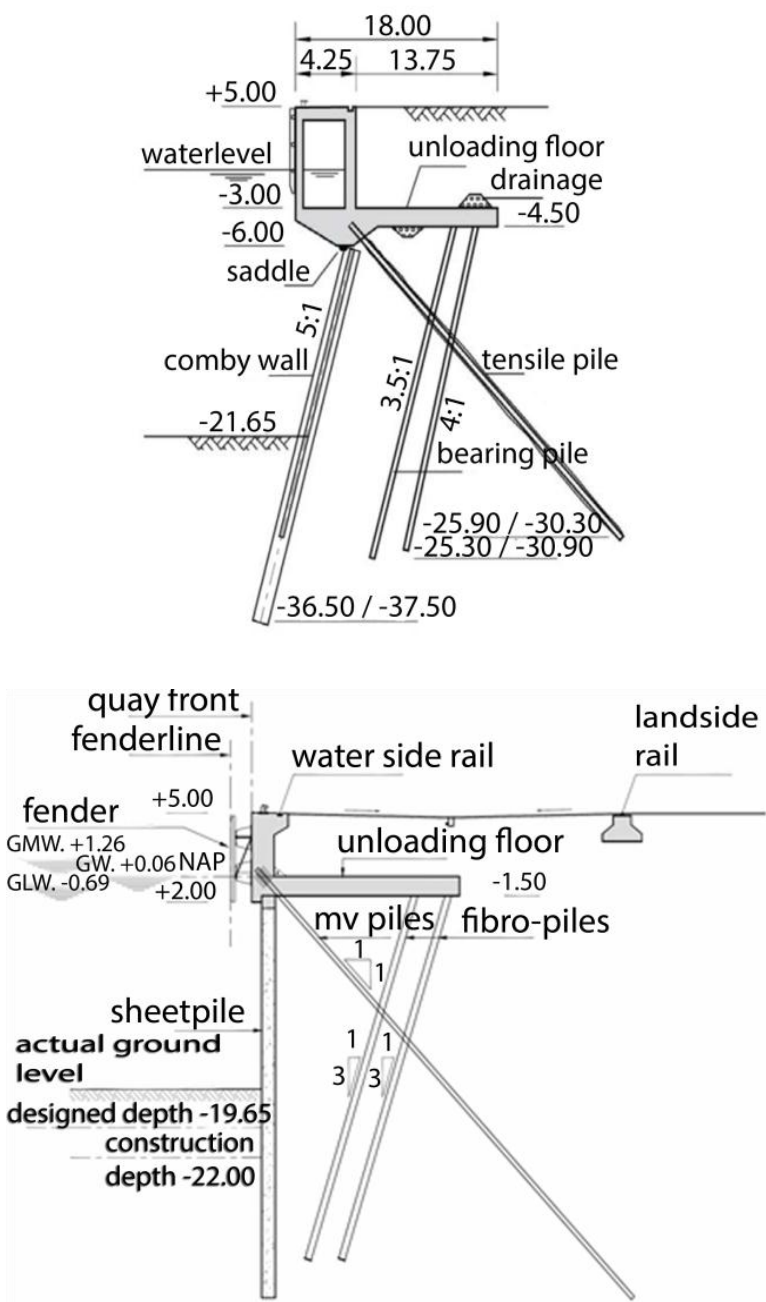

Figure 17. Two Examples of Relieving Floor Structure One with a Combiwall and One with a Slurry Wall

The increase in dimensions of container cranes, especially the outreach, is shown in Figure 18. The outreach increased from 10 to $70 \mathrm{~m}$ in 60 years. Now two containers are handled. This might increase to 5 in the near future.

The increase in container handling capacity of the cranes result in considerably higher moments as shown in Figure 19, and thus crane loads on the foundations. This subject has to be researched in more detail.

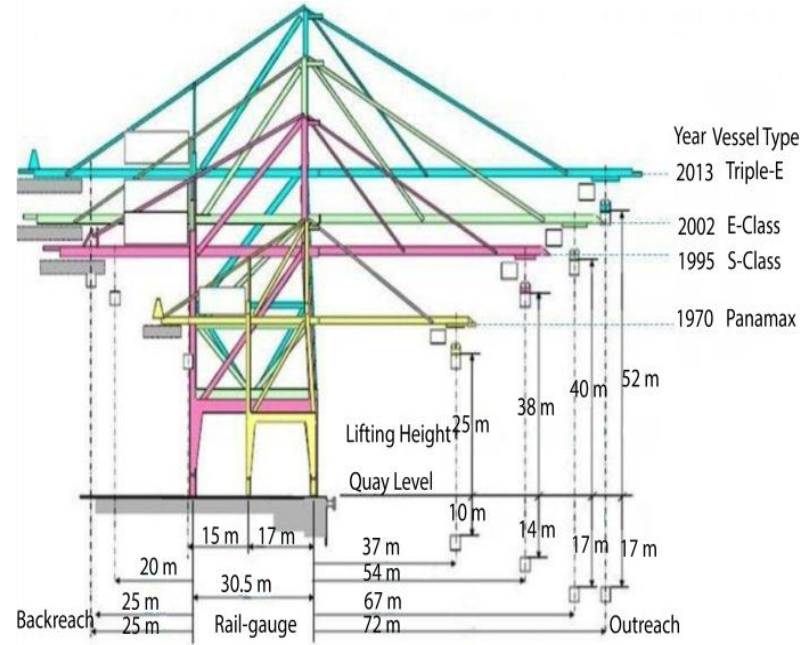

Figure 18. Indication of the Dimensions of Container Cranes [15]

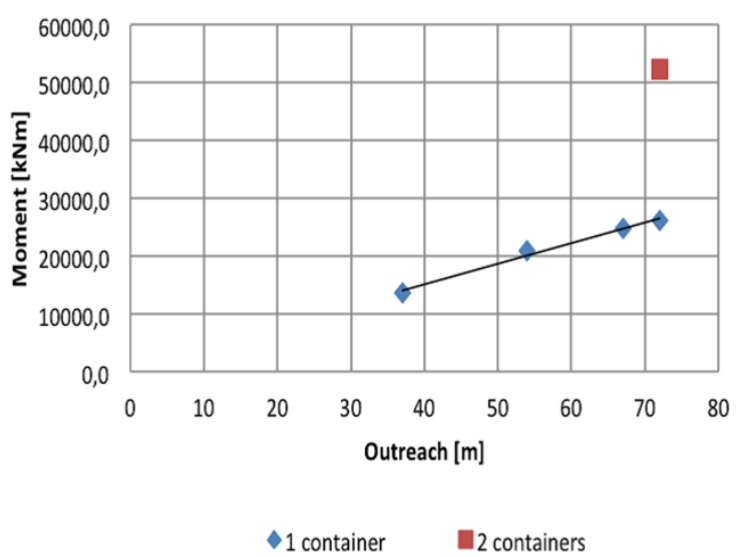

Figure 19. Impact of Increase in Outreach on the Moment [15]

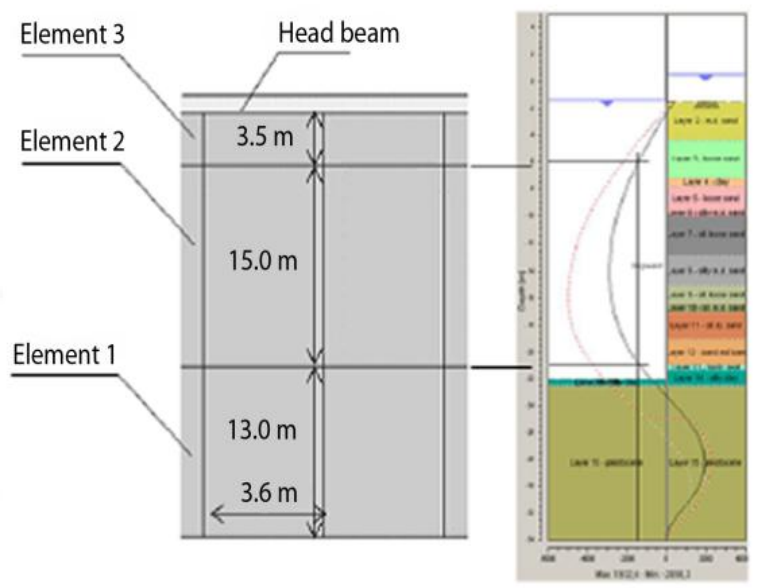

Figure 20. Elements of Prefab Slurry Wall

This construction type has been investigated, Figure 20 , as removal of a standard slurry wall is extremely costly and it has no rest value. With this option, it should be in principle possible to reuse the part of the elements i.e. as a wall in a parking garage. 
Recently a quay wall has to be removed in the Amazonehaven Rotterdam to make the harbour basin wider. However during removal of this quay wall, it appeared that the combiwall and sheet pile elements were considerably damaged $[13,16]$. The influence of this damage is being investigated with the finite element technique, Figure 21. With the aid of this type of programmes, i.e. PLAXIS 2 and 3-D effects of a quay wall can be analysed [16]. Also a load testing of this structure will be performed and simulated, as this was too expensive to carry out in situ.

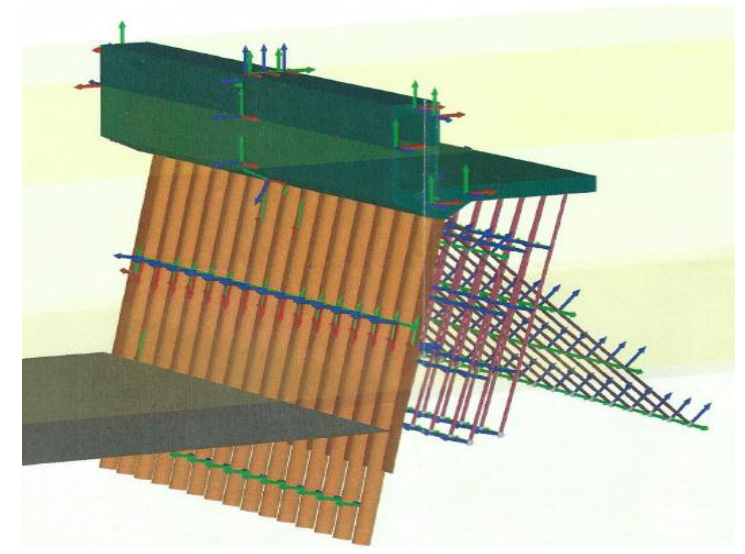

Figure 21. Finite Element Composition of Quay Wall with Relieving Floor

\section{Maasvlakte 2}

The Maasvlakte 1 area, Figure 22, has been reclaimed from North Sea during 1960-1970. The Maasvlakte 2 area, about 2000 hectares has been reclaimed from the sea and is protected with what is called a combination of soft and hard sea defence during the period of 2000-2014. The soft sea defence consists of a sloping beach of 1:20 made with sea sand. The harbour entrance however is constructed as a composite construction combining sand and gravel and reused concrete blocks. The construction is shown in Figure 23. This construction is behaving very well.

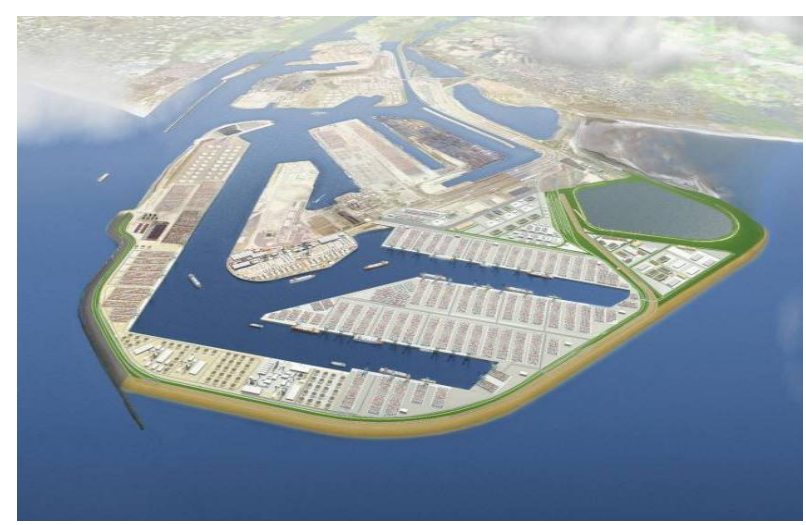

Figure 22. Maasvlakte 1 and 2

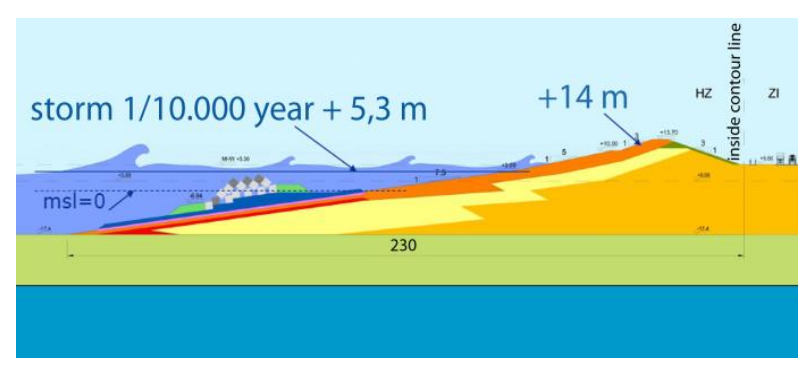

Figure 23. Breakwater Structure at North West Corner of Maasvlakte 2

This structure is composed of sand and gravel layers, while at the level of mean sea level the reused blocks are placed to reduce wave run up. In this way the crest height of the dam could be reduced by $3 \mathrm{~m}$.

The costs of reclaiming land are less then $€ 250 / \mathrm{m}^{2}$ [17]. However, the sea front rates per $\mathrm{m}^{2}$ vary between $€ 485$ to $€ 35000$ [17]. depending on the location.

This Figure 24 shows the especially block handling equipment to remove the blocks from the former breakwater of Maasvlakte 1 and place the blocks at the new dam.

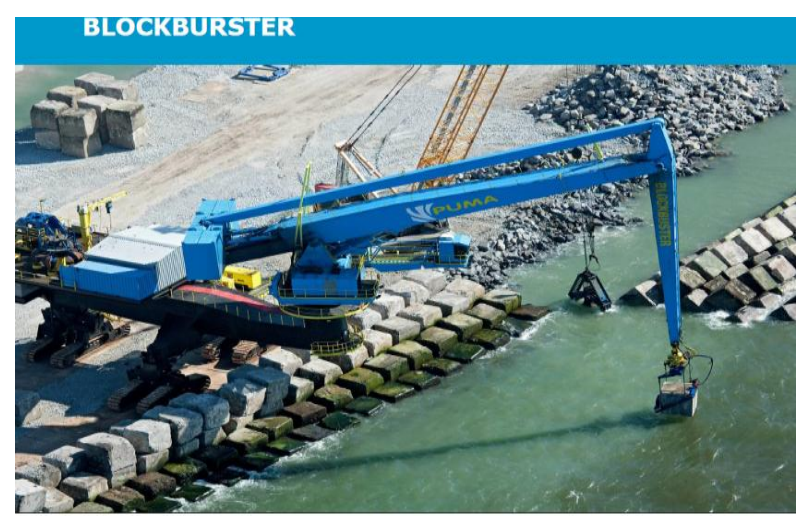

Figure 24. Block Handling Equipment

\section{Design Procedures}

Today semi-probabilistic analysis are performed using the Eurocodes for all structures in the Netherlands.

The biggest advantage using semi-probabilistic tools is that both at the load, as well as at the resistance side, the uncertanties are considered. These uncertainties are valued with partial factors. For quay wall structures, these method is presented in references [14,18].

With the aid of a fault tree the risks of structures can be analysed and on the basis of this actions can be taken by the parties involved. An example of a fault tree of a quay wall is given in Figure 25. 


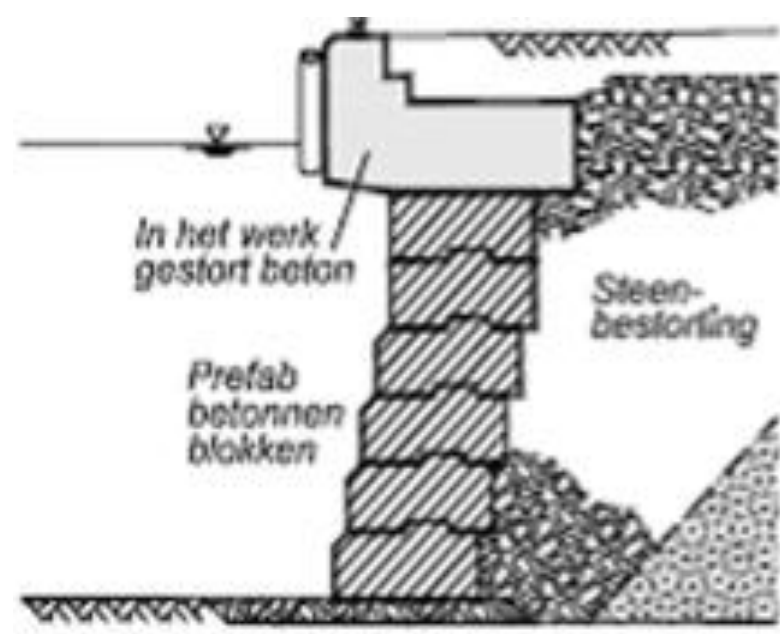

Figure 25. Fault Tree of Blockwall Type Quay Wall

\section{Recommendations and Conclusions}

- Building hydraulic structures has stimulated shipping at rivers and canals as well over the ocean.

- Further, drinking water problems have been solved as well as the irrigation of land for increasing the productivity of agriculture.

- Dams on land are not only used for the storage of water but also for generating energy.

- The value of all these structures is immense and thus requires attention in general for decision makers however also for the education of students.

- This implies that one have to train young people to find an optimal technical and economical design. This should include the whole lifecycle costs thus costs for engineering, construction, maintenance costs, demolishing costs and environmental costs.

- It has been shown that the structures have become bigger and at the same time have improved due to the increased knowledge in fundamental behaviour of the disciplines involved. Also the construction possibilities have become dramatically better and more effective resulting in shorter building periods.

- Hydraulic structures give human the chance to develop their prosperity and economy and represent an enormous amount of money and these investments must made profitable for society.

\section{References}

1. Ansar, A. et al., Should We Build more Large Dams? The Actual Costs of Hydropower Megaproject Development, Energy Policy, 2014.

2. de Gijt, J.G., van Kleef, J.M., Development of Port Design and Construction in the Port of Rotterdam, International Conference on PortMaritime Development and Innovation, 5-7 September 2005, Rotterdam, The Netherlands, 2005.

3. Needham, J. Science and Civilisation in China, 1(6), 1986, Cambridge, Cambridge University Press.

4. Wikipedia, Dams, Locks Innovations in Navigation Locks, PIANC Report no: 106,2009

5. www.portofantwerp.be

6. Diekman, J.E., Past Perfect: Historical Antecedents of Modern Construction Practices, ASCE Journal of Construction and Management, September, 2005

7. de Gijt, J.G., A History of Quay Walls, $\mathrm{PhD}$, Delft University of Technology, 2010.

8. De Bosatlas van Nederland Waterland ISBN 9789001/14 131211 10,2010

9. Sinking Cities, an Integrated Approach towards Solutions, Deltares, 2013.

10. De Ingenieur no 18, Ruimte voor de rivier.

11. Mooyaaart L., Jonkman S.N., Vries de P., van der Thoorn A., and Ledden M., Storm Surge Barrier: Overview and Design Considerations, Coastal Engineering Proceedings, 2014.

12. www.rijkswaterstaat.nl

13. Broos, E.J. and de Gijt, J.G., The Demolishing of the EMO Quay Wall in the Amazonehaven, Port of Rotterdam, HTG Congress 2014, Berlin, 21-23 May 2014.

14. de Gijt, J.G. and Broeken, M.L., Quay Walls, 2013, Francis Taylor editors.

15. Tisheh, I., Vellinga, T., de Gijt J.G., Braam, C.R., and Broos, E.J., The Feasibility Research of Standard Quay Walls for the Port of Rotterdam, MSc Thesis 2015 TUDelft.

16. Mourillon, M., Bakker, K.J., de Gijt, J.G., Broos, E.J., and Vellinga, T., Research into the Damage of the Demolised Quay Wall in the Aamazonehaven, M.Sc Thesis, 2015, TU Delft.

17. Kolman, R., Newland in the Water, Economically and Socially, Land Reclamation, Terra et Aqua, 128, September 2012.

18. de Gijt, J.G., Lecture Notes Port Infrastructure, CT 5313, 2014 TU Delft. 